\title{
DOES SELF-EFFICACY PLAY AN INTERVENING ROLE? STUDYING BETWEEN ORGANIZATIONAL CLIMATE AND JOB INVOLVEMENT
}

\author{
Nancy Yusnita ${ }^{a^{*}}$ \\ ${ }^{a)}$ Universitas Pakuan, Bogor, Indonesia \\ ${ }^{*}$ Corresponding Author: nancyyusnita@unpak.ac.id
}

Article history: received 29 January 2021; revised 13 February 2021; accepted 26 February 2021

\begin{abstract}
Many pieces of research on job involvement had generated findings that job involvement is considered to be one of the main ways to increase employees' performance. The objective of this study is to examine factors that have a relationship with job involvement namely organizational climate and self-efficacy. By finding the important factors that influence job involvement, it is expected that efforts to increase job involvement are useful for enhancing performance This study was conducted among lecturers at 4 private universities in Bogor, Indonesia. The sample for the study consisted of 252 lecturers derived randomly from its population. The study mainly utilized quantitative data (from questionnaires). The regression analysis was used to find out the relationship among variables. The findings revealed that organizational climate had a positive effect on job involvement. Similarly, self-efficacy had a positive effect on job involvement. The further organizational climate had a positive effect on job involvement through self-efficacy. The research result showed that self-efficacy as the intervening had significant a role in the effect of organizational climate on job involvement. Also, based on those findings, this study proposed some recommendations toward private universities to strengthening the self-efficacy of the lecturers to increasing their job involvement to increase performance
\end{abstract}

Keywords: organizational climate, self-efficacy, job involvement, performance

\section{INTRODUCTION}

Every institution certainly expects a high level of involvement in the work of its employees. Employees who have high job involvement will show higher participation in achieving organizational goals (Lawler, E.E, \& Hall, D.T [1]) Highly engaged employees have higher motivation for the interests of their work and organization. Furthermore, employees who have high work involvement show better professional relationships with colleagues and superiors (Brown, S.P., [2]). A person who has high work involvement has loyalty to his/her job and organization.In recent times, many organizations and managers are paying high attention to employee involvement in their work and organization. High turnover will have a financial impact on a company, to find and recruit new employees.

Job involvement is also expected to show a positive correlation with employee response to work instructions and a negative correlation to leave work (Hallberg,U.E, \& Schaufeli,W. B [3]. Brown [2] states that people who are involved in work show recognition that their work is important, motivating, and challenging, (b) have an emotional connection with their work, give all the best for their work, have a desire to stay at their job (c) have an emotional connection. better communication and engage more closely in professional relationships with supervisors and coworkers.Many factors affect the work involvement of an employee, including organizational climate and selfefficacy (Colquitt [4]). Organizational climate is the members' shared perception of the organization in which they work in terms of policies, work rules, working conditions, and other management practices. (Uhl-Bien [5]). Organizational climate includes perceptions of organizational members on superior-subordinate relationships, communication that exists between members of the organization and members 'perceptions of organizational policies, members' perceptions of management practices (fairness). A member of an organization who feels comfortable in his or her organizational environment and feels treated fairly by the organization will have a close psychological relationship with the job and the organization where he works (Kanungo, R.N. [6]).

The warm organizational climate felt by the members of the organization will make them feel comfortable and earnestly give their all for the job. A high level of job involved from organizational members is manifested in the active participation of an individual in his work. According to Colquitt [4], apart from organizational factors, individual factors also play an important role in the level of job involvement of an employee.

Self-efficacy (beliefs about a person's ability to complete certain tasks in certain situations) is reflected in the tasks employees choose to perform and influence the goals they set for themselves. Self-efficacy also affects the level of effort and persistence of employees when faced with difficult tasks. The four sources of self-efficacy are past performance, vicarious experiences, verbal persuasion, and emotional cues. Managerial and organizational implications 
of self-efficacy in the workplace include hiring and promotion decisions, training and development, and goal setting. (Lunenburg [7])

Low job involvement in turn reduces self-efficacy and vice versa, low self-efficacy will result in their low job involvement to work well and contribute to the institution. They feel less interest in completing tasks and try to escape the extra-role behavior and avoid extra tasks (Srivastava \& Dhar [8]). Job involvement mainly depends on intrinsic factors, which is factors that come from an individual, this will be positively correlated with the notion that the importance of performance for one's self-esteem (Lawler, E.E, \& Hall,D.T [1]).

Job involvement is an individual's view of the extent to which his work can satisfy his self-esteem needs (Kanungo [6]). The concept of job involvement reflects an individual's active participation in his job tasks (Schermerhorn [9]). People with high job involvement are dedicated and have a psychological relationship with their job roles (Kreitner \& Kinichi [10]; Robbins [11]). People who have high work involvement consider it important to do tasks outside their responsibility (Kreitner \& Kinichi [10]). Compared with individuals with low job involvement, individuals who are highly engaged in work perceive that work is more closely related to their self-esteem (Lodahl \& Kejner [12]; Thoits [13]).

An organization must create an atmosphere that can evoke high job involvement from its employees, with policies and management that support an employee will be willing to participate actively in his work and assume that work is important in his/her life. Organizational climate has become one of the main factors used to differentiate an organization from other organizations which is determined by the characteristics of procedures, strategies, and physical environment, and the psychological nature of its employees (Dunnette \& Hough [14]).

Organizational climate defined as employees' perceptions of the workenvironment and these perceptions influence individuals' work- related attitudes and behaviours in problem solving and complete the task (Adenike, [15]). Organizational climate is measured with indicators: management and leadershipstyles, participation in decision making, challenging jobs, boredom and frustration, fringe benefits, personnel policies, working conditions, suitable career ladder. organizational culture is a system of shared meanings of shared values and shared by the organization [16]. Organizational climate is known to have a significant effect on the performance of members of educational organizations (Musah [17]; Pashiardis, [18]). Organizational climate is believed to have influenced the tendency towards innovation, improvement and change in terms of the application of quality principles (Freed [19]). Thus, a healthy climate results in an increased level of employee commitment to the organization in which they work. Musah [17] and Rahimic [20] found a positive relationship between $\mathrm{OC}$ and employee satisfaction and performance.
Organizational climate as a perceptual and cognitive structure of the general organizational situation felt by organizational members. Within the organization there are work behaviors that apply and are understood by members of the organization as routines and processes (Balachandran, [21]). When organizational members interact with each other, there is an exchange of experiences and perceptions; There are many personal cognitive maps that face each other and are modified. In this way, a general way of understanding and emerging as a rule that applies to organizational members (Padaki [22]).

The organization is made up of many people with various backgrounds in family, education experiences, and skills, it is what distinguishes an individual from other individuals in the way they perceive and complete work. Self-efficacy is defined as an individual's belief that they are able to achieve goals and perform certain tasks in certain situations (Bandura [23]; Hefferon \& Boniwell [24]; Luszczynska, Scholz, \& Schwarzer, [25]; Robbins, Decenzo, \& Coulter [11]; Schermerhorn [9]). Self-efficacy is reflected as 'the power of I can' (Hefferon \& Boniwell [24]). Research has shown that individuals who have a high level of selfefficacy have more confidence in their abilities, and are brave enough to face challenges and obstacles at work than individuals with lower levels of self-efficacy. A low level of self-efficacy causes individuals to reduce their efforts to face challenges and obstacles (Cetin \& Basim, [26]; Robbins [11]).

self-efficacy is a person's self-assessment of his or her ability to take action in achieving a certain performance. This is mainly related to his confidence in the skills he possesses to complete tasks (Bandura [27]). People who have high self-efficacy will act more expressively because of their self-confidence (Luszczynska, and Schwarzer, [28]). Chang and Chien [29] revealed that self-efficacy refers to individual abilities that can be used to complete work, control behavior, and assess work results of Putwain [30] concluded that self-efficacy can predict performance and can predict emotions, this can be seen from work performance (Noreen [31]) concluded that self-efficacy affects work results. Thus, individuals with low self-efficacy will easily give up when facing obstacles and individuals with high self-efficacy will survive the obstacles and try to solve them completely. Putwain [30] concluded that self-efficacy can predict academic performance and can predict the emotional state of a person.

Noreen, [31] Individuals with low self-efficacy will easily give up when they face difficulties in completing their tasks, while individuals with high self-efficacy will survive these difficulties and try hard to complete their task.

From the opinion and the finding of previous research of the experts above we can conclude that Organizational climate refers to the shared perceptions of organizational members about the organization and works environment Dimensions of organizational climate: innovation is a new invention, creativity is a mental process that involves 
generating ideas, communication is the process of using the information to connect with the environment, warmth, namely the existence of friendly and friendly special groups. support, involvement, namely the existence of participation, safety, namely a state of security, justice, namely the ideal conditions regarding something, diversity and customer service

Research by Pourkaini [32], on Studying the Relationship Between Organizational Climate and Job Involvement and Intermediary Role of Organizational Commitment Among Employees of Mashhad Melli Bank, shows that there is a positive influence on organizational climate on work involvement variables. (job involvement) $(\Phi=0.83 \mathrm{p}<0.05)$. This means that there is a very strong positive influence from organizational climate on job involvement. Research conducted by Srivastava [8] on Examining Correlates between School Teachers' SelfEfficacy and Their Job Involvement shows that there is a positive influence on the self-efficacy variable on work involvement variables $(\Phi=0.793 \mathrm{p}<0.05)$. This means that there is a strong positive influence of organizational climate on job involvement.

Based on the theory and results of previous research, we propose three research hypotheses, they are:

- There is a positive effect of organizational climate on job involvement

- There is a positive effect of self-efficacy on job involvement

- There is a positive effect of organizational climate on job involvement through self-efficacy

\section{RESEARCH METHODS}

The study conducted at 4 private universities in Bogor during March up to December 2019, and mainly utilized quantitative data (from questionnaires). The amount of 252 sample calculated by Slovin formula at $\mathrm{p}<0.05$ and randomly took from 630 permanent lecturers as the population. The questionnaires designed to assessed indicators of Job Involvement, Organizational Climate and Self-Efficacy using point of 1 to 5 Likert Scale. The questionnaires had already tried out used 30 sample from its population but out of research sample in order to measure each validity and reliability as reported in the table below.

Table 1. The Valid Items and Reliability of the Questionnaires

\begin{tabular}{|c|l|c|c|}
\hline No & \multicolumn{1}{|c|}{ Questionnaire of } & $\begin{array}{c}\text { Sum of Valid } \\
\text { Items }\end{array}$ & $\begin{array}{c}\text { Reliability } \\
\text { Coefficient }\end{array}$ \\
\hline 1 & Job Involvement & 42 & 0.943 \\
\hline 2 & Organizational Climate & 43 & 0,944 \\
\hline 3 & Self-Efficacy & 37 & 0.965 \\
\hline
\end{tabular}

Notes:

1. Each questionnaire initially had 50 items of Job Involvement, 50 of Organizational Climate, 43 of Self-Efficacy and already tried out (used 30 sample). Some item were dropped-out, and the rest is the valid items only. The item validity coefficient calculated by Pearson's Product-Moment Correlation formula (Nolan \& Heinzen [33]).
2. The questionnaires reliability coefficient calculated by Cronbach Alpha's formula (Sekaran \& Bougie [34]).

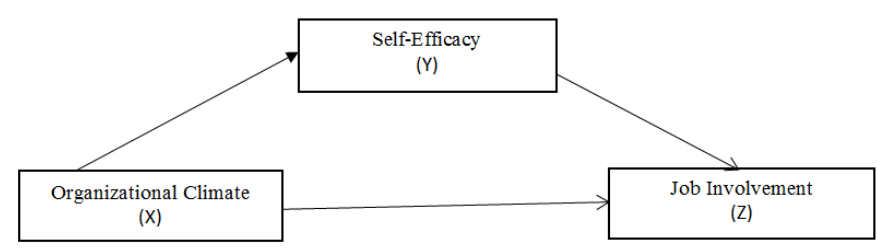

Figure 1. The research design.

All data collected as the feedback from the distributed questionnaire from 252 lecturers as the research respondent will be analyzed step by step. The analysis used the Structural Equation Modelling (SEM) method. SEM forms two types of models, namely measurement models, and structural models. The measurement model aims to describe how well each indicator can be used as an instrument for measuring latent variables through testing the validity and reliability of the indicators and dimensions of the research variables. The structural model is a model. where the goodness of fit for the inner model can be proven by examining the effect of each exogenous latent variable on the endogenous latent variable. Overall, this research consists of three variables, namely, Organizational Climate (OC), Self-Efficacy (SE), and Job Involvement (JI).

\section{RESULTS AND DISCUSSION}

The results of the data processing above indicate that the influence of organizational climate on job involvement through self-efficacy has a greater regression coefficient (0.254) compared to the direct effect of organizational climate on job involvement (0.19).

Table. 2 Analysis (goodness of fit test) Model

\begin{tabular}{|l|l|r|c|}
\hline \multicolumn{1}{|c|}{ GOF } & \multicolumn{1}{|c|}{ Cut off Value } & \multicolumn{1}{c|}{$\begin{array}{c}\text { Research } \\
\text { result }\end{array}$} & Conclusion \\
\hline Chi-square $\left(\chi^{2}\right)$ & \multicolumn{1}{c}{ Df } & 345,72 & \\
\hline Df & & 227 & \\
\hline $\begin{array}{l}\text { Chi-square } \\
\left(\chi^{2}\right) / d f\end{array}$ & $\begin{array}{l}\leq 3 \\
(2: 1 \text { (Tabachnik and } \\
\text { Fidell 2007) and } \\
3: 1 \text { (Kline 2005) }\end{array}$ & 1,52 & good fit \\
\hline $\begin{array}{l}\text { Probability } \\
\text { (P-value })\end{array}$ & $\leq 0,05$ & 0,000 & good fit \\
\hline & $\begin{array}{l}\text { Model that have less } \\
\text { RMR } \\
\text { (Tabachnik and Fidell }\end{array}$ & 0,052 & good fit \\
RMR & $\begin{array}{l}2007), \leq 0,05 \text { or } 0,08 \\
\text { (Hair } \text { et al. } 2007)\end{array}$ & & \\
\hline RMSEA & $\leq 0,08$ & 0,046 & good fit \\
\hline GFI & $\geq 0,90$ & 0,893 & Marginal fit \\
\hline AGFI & $\geq 0,90$ & 0,87 & Marginal fit \\
\hline CFI & $\geq 0,90$ & 0,991 & good fit \\
\hline NFI & $\geq 0,90$ & 0,978 & good fit \\
\hline NNFI & $\geq 0,90$ & 0,991 & good fit \\
\hline RFI & $\geq 0,90$ & 0,976 & good fit \\
\hline IFI & $\geq 0,90$ & 0,992 & good fit \\
\hline
\end{tabular}


Table 3. Score of SLF and t-value Model
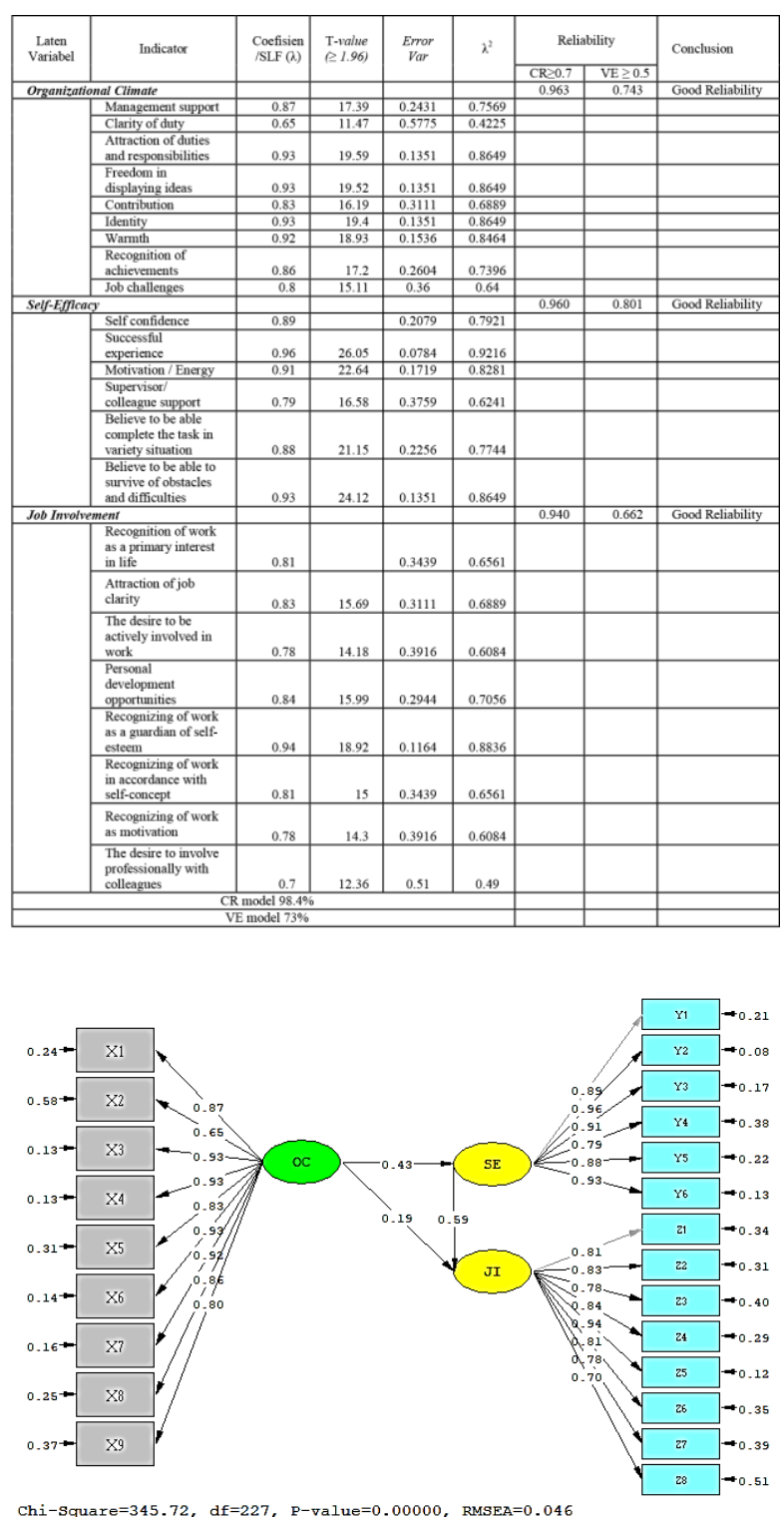

Figure 1. Output Standardized SolutionSEM Lisrel 8.80 Model 1

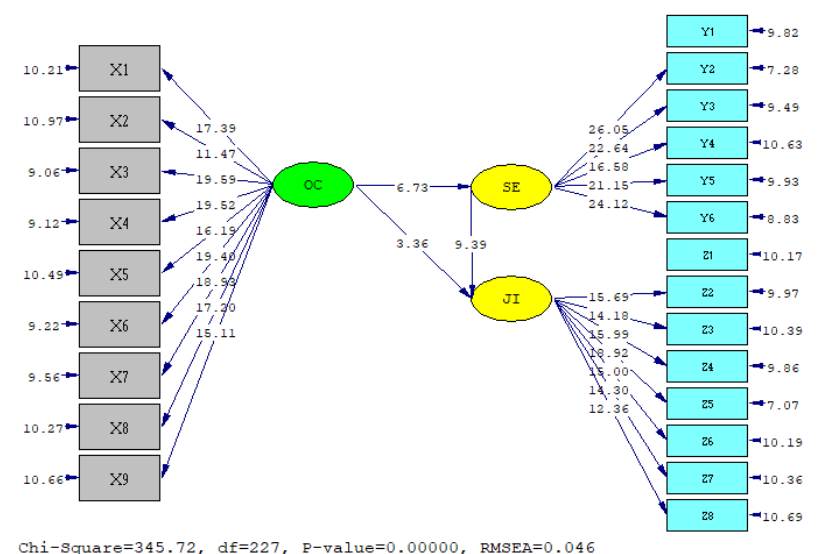

Figure 2 Output t-value SEM Lisrel 8.80 Model 1
Table 4 Hypotheses Test Result

\begin{tabular}{|c|c|c|c|c|c|c|}
\hline \multirow{2}{*}{$\begin{array}{l}\text { Hypotheses } \\
\text { Alternatif } \\
\text { (Ha) }\end{array}$} & \multirow[b]{2}{*}{ path } & \multirow[b]{2}{*}{$\begin{array}{l}t \text { count } \\
(\geq 1,96)\end{array}$} & \multicolumn{3}{|c|}{ regression } & \multirow[b]{2}{*}{$\begin{array}{l}\text { Hypotheses } \\
\text { Conclusion }\end{array}$} \\
\hline & & & direct & $\begin{array}{c}\text { Through } \\
\text { Intervening }\end{array}$ & Total & \\
\hline $\mathrm{Hl}$ & $\mathrm{OC} \rightarrow \pi$ & 3.36 & 0.19 & & 0.19 & Accepted \\
\hline $\mathrm{H} 2$ & $\mathrm{SE} \rightarrow J I$ & 9.39 & 0.59 & & 0.59 & Accepted \\
\hline $\mathrm{H} 3$ & $\mathrm{OC} \rightarrow \mathrm{SE}$ & 6.73 & 0.43 & & 0.43 & Accepted \\
\hline $\mathrm{H} 4$ & $\mathrm{OC} \rightarrow \mathrm{SE} \rightarrow \mathrm{JI}$ & 3.36 & 0.19 & $\begin{array}{c}0.43 \times 0.59 \\
=0.254\end{array}$ & 0.444 & Accepted \\
\hline
\end{tabular}

The finding of this study are in line with the results of the study conducted by Yangjuan [35] and Widodo, S. [36] Indicators Loading Factor analysis shows that the successful experience indicator has the highest loading factor among the self-efficacy indicators (0.96). Self-efficacy is defined as an individual's belief that he or she is capable of completing a task in certain situations. The organizational climate that is perceived as positive and supportive by members of the organization will affect the level of confidence in a person to be able to complete his job. Factors that influence the level of a person's self-efficacy are the experience of success, social modeling, social persuasion, and physical and emotional conditions. A person who has the experience of completing a task in the past will have high confidence that he will be able to complete the work in future assignments in certain situations and conditions and is willing to accept job challenges. A person who has high self-efficacy will have high self-confidence so that he will provide more participation in his job (job involvement).

\section{CONCLUSION}

The scope of this study had limitations. Population and sample of lecturers utilized in this study just 4 private universities. So the results of this study can be generalized to its population only. This study just investigated two variables (organizational climate and self-efficacy) that had relationship with job involvement. Theoretically, it can be identified that many variables might have influenced job involvement. We recommend for the next other studies to utrilize a large population and sample and also investigate more variables that might influence job involvement.

Research findings show that self-efficacy does play an effective intervening between organizational climate and job involvement, self-efficacy provides a greater effect of organizational climate on job involvement. From the loading factor analysis, it can be seen that the successful experience indicator has the highest loading factor of the self-efficacy variable. We can say that someone who has had success in completing tasks will have high job involvement. We recommend that organizations, especially educational institutions, increase the self-efficacy of lecturers by providing self-efficacy training and provide many opportunities for lecturers to be involved in various activities both teaching and research so that lecturers have a lot of experience in completing work. The results of the research found that a person who has experience of success will have high job involvement. 


\section{REFERENCES}

[1] Lawler, E.E, \& Hall,D.T 1970. Relationship of Job characteristics to job involvement, satisfaction, and intrinsic motivation. Journal of Applied Psycology ,54,305-312

[2] Brown.S.P 1996. A Meta analysis and review of organizational research on job involvement. Psycological Bulletin, 2,235-255.

[3] Hallberg,U.E, \& Schaufeli.Wilmar B 2006. Can Work Engagement be discriminated from Job Involvement and Organizational Commitment. Journal of European Journal of Psycologist vol 11(2): 119-127.

[4] Colquitt, J.A.. 2008. Two decades of organizational justice: Findings, controversies, and future directions. 10.4135/9781849200448.n5.

[5] Mary Uhl-Bien, John R. Schermerhorn, Jr., \& Richard N. Osborn. Organizational Behavior. Hoboken, NJ: John Wiley \& Sons, 2014, p. 13.

[6] Kanungo, R. N. 1982. Measurement of job and work involvement. Journal of Applied Psychology. Vol 67, pp $341-349$.

[7] Lunenburg, Fred C. Self-Efficacy in the Workplace: Implications for Motivation and Performance International Journal of Management, Business and Administration. Vol 14, number 1, 2014 pp 1-6

[8] Srivastava, A. P., \&Dhar, R. L. 2015. Training comprehensiveness: construct development and relation with role behaviour. European Journal of Training and Development, 39(7), 641 - 662.

[9] Schermerhorn, J. R., Hunt, J. G., Osborn, R. N., \& Uhl-Bien, M. 2011. Organizational behavior. Asia: John Wiley \& Sons (Asia) Pte Ltd.

[10] Kreitner, R., \& Kinichi, A. 2009. Organizational behaviour. New York: Mc Graw-Hill International Edition, Ninth edition.

[11] Robbins, S. P., Decenzo, D. A., \& Coulter, M. 2013. Fundamentals of management: Essential concepts and applications (8th Edition). New Jersey: Pearson Education.

[12] Lodahl, T. M., \& Kejner, M. 1965. The definition and measurement of job involvement. Journal of Applied Psychology. Vol 49, pp. $24-33$.

[13] Thoits, P. A. 1991. On merging identity theory and stress research. Social Psychology Quarterly, Vol. 54, pp $101-112$.

[14] Dunnette, M. D. \& Hough, L. M. 1998. Handbook of Industrial and Organisational Psychology (Eds.), Vol. 4, Delhi: Jaico Publishing House.

[15] Adenike, A. 2011. Organizational Climate As a Predictor of Employee Job Satisfaction: Evidence From. Business Intelligence Journal, 4(1), 151-165.

[16] Y. Suchyadi, "Relationship between Work Motivation and Organizational Culture in Enhancing Professional Attitudes of Pakuan University Lecturers," JHSS (JOURNAL Humanit. Soc. Stud., vol. 01, no. 01, pp. 41-45, 2017.
[17] Musah, M.B. 2013, "Exploring the relationship between quality culture and organisational climate with workforce performance", Unpublished Doctoral dissertation, International Islamic University Malaysia.

[18] Pashiardis, P. 1996, "Towards effectiveness: campus climate at the University of Cyprus", Annual Forum Paper, ERIC Document Reproduction Service.

[19] Freed, J.E., Klugman, M.R. \& File, J.D. 1997. A culture for academic excellence implementing the quality principles in higher education. ASHE-ERIC, Higher Education Reports. Vol 25 No.1

[20] Rahimic, Z. 2013, "Influence of organizational climate on job satisfaction in Bosnia and Herzegovina companies", International Business Research, Vol. 6 No. 3, pp. 129-139. doi: 10.5539/ibr.v6n3p12.

[21] Balachandran, M. \& Thomas, I. 2007 Dimensions of Organisational Climate. The PSYCHESPACE Journal. Vol. 1, No.1, pp 27-36.

[22] Padaki, R. 1982. A Study of Organisational Climate and Work Behaviour, Ph. D. Thesis, Gujarat University: Ahmedabad.

[23] Bandura, A. 2002. Social cognitive theory in cultural context. Journal of Applied Psychology: An International Review. Vol 51, pp 269-290.

[24] Hefferon, K., \& Boniwell, I. 2011. Positive psychology: Theory, research and applications (1th edition). New York: Mc Graw-Hill Open International Publishing Ltd.

[25] Luszczynska, A., Scholz, U., \& Schwarzer, R. 2005. The general self-efficacy scale: Multicultural validation studies. The journal of Psychology, 139(5), 439-457.

[26] Kalemci Tuzun, Ipek \& Çetin, Fatih \& Basım, Nejat. 2014. The role of psychological capital and supportive organizational practices in the turnover process. 41. 85-103.

[27] Bandura, A. 1986. Social foundations of thought and action. Englewood Cliffs, NJ: Pearson

[28] Luszczynska, Aleksandra, \& Ralf Schwarzer. 2005. "Social cognitive theory." Predicting health behaviour 2: 127-169

[29] Chang, F. D., \& Chien, C. W. 2015. Determining the relationship between academic self efficacy and student engagement by meta analysis. 2nd International Conference on Education Reform and Modern Management, Hong Kong. https://doi.org/10.2991/ermm-15.2015.37

[30] Putwain, D., Sander, P., \& Larkin, D. 2013. Academic self-efficacy in study-related skills and behaviours: Relations with learning-related emotions and academic success. British Journal of Educational Psychology, 83(4), 633-650. doi: https://doi.org/10.1111/j.2044- 8279.2012.02084.x.

[31] Noreen, S., Hasan, A., Batool, I., \& Ali, A. 2018. The Impacts of Academic SelfEfficacy on Academic Outcomes: The Mediating effect of Student Engagement. International Journal of Academic 
Research in Business and Social Sciences, 8(11), 315-327. doi: https://doi.org/10.6007/IJARBSS/v8i11/4904.

[32] Pourkaini, M. et.al, 2014. Studying The Relationship Between Organizational Climate and Job Involvement and Intermediary Role of Organizational Commitment Among Employees of Mashhad Melli Bank. Indian Journal of Fundamental and Applied Life Sciences ISSN: 2231- 6345 (Online) An Open Access, Online International Journal Available at www.cibtech.org/sp.ed/jls/2014/04/jls.htm 2014 Vol. 4 (S4), pp. 670-680.

[33] Nolan, S.A. and T.E. Heinzen. 2012. Statistics for the Behavioral Sciences. New York: Worth Publisher.

[34] Sekaran, U. and R. Bougie. 2013. Research Methods for Business. West Sussex, UK: John Wily \& Sons.

[35] Yangjuan, B., Wipada, K. \& Samjai, S. 2013. Organizational Climate and Self -Efficacy among Nurses in University Hospitals, Yunnan Province. The People's Republic of China. Nursing Journal. Vol. 40, No 4, pp 139-149.

[36] Widodo, S. 2010. Pemberdayaan Salah Satu Fungsi Pokok Manajemen. Jurnal Pendidikan Tinggi. Vol. 3, No.1, p 28. 